\title{
MEKANISME DAN STRATEGI MENGURANGI STRESS PADA PASIEN KUSTA
}

\section{(Mechanisms and Coping Strategies that Affect the Stress of Leprosy Patients: A Systematic Review)}

\author{
Atika Jatimi, Aplonia Nenobais, Moh Jufriyanto, Maulidiyah Junnatul Azizah Heru and Ah Yusuf
}

Fakultas Keperawatan, Universitas Airlangga, Surabaya, Indonesia

\section{RIWAYAT ARTIKEL}

Diterima: 10 Desember 2018

Disetujui: 15 Februari 2019

\section{KONTAK PENULIS}

Atika Jatimi atika.jatimi2018@fkp.unair.ac.id

Fakultas Keperawatan, Universitas Airlangga

\begin{abstract}
ABSTRAK
Pendahuluan: Kusta merupakan penyakit menular yang menyebabkan permasalahan yang kompleks. Permasalahn tidak hanya dari aspek medis, fisik dan psikologis penderita, tetapi dapat meluas pada masalah sosial seperti penerimaan masyarakat terhadap orang yang terkena kusta, budaya dan ekonomi yang dikaitkan dengan dengan sumber pendapatan dan pekerjaan.
\end{abstract}

Metode: Media pencarian artikel melalui database berikut: Scopus, Google Scholar, Science Direct, PubMed, dan Proquest. Lima belas artikel ditinjau, 6 strategi koping pada pasien kusta yang mempengaruhi stres termasuk membaca buku, program kesadaran sosial, stigma, penerimaan, dukungan sosial dan pengetahuan

Hasil: Dari hasil analisis, ini dapat diterapkan untuk memberikan dukungan bagi orangorang yang terkena kusta untuk mengubah mekanisme koping mereka agar mereka lebih adaptif.

Kesimpulan: Strategi-strategi ini perlu dipertimbangkan untuk menentukan tingkat koping individu dalam menghadapi stimulasi stres pada pasien dengan kusta yang berasal dari diri mereka sendiri, orang lain dan lingkungan.

\section{Kata Kunci}

Strategi, stress, kusta, koping

\section{ABSTRACT}

Introduction: Leprosy is an infectious disease that still causes very complex problems. The problem is not only from the medical, physical and psychological aspects of the sufferer but it also extends to social problems such as the community acceptance of people affected by leprosy, culture and the economy related to income sources and employment

Method: We searched for articles within the following databases: Scopus, Google Scholar, Science Direct, PubMed and Proquest. Fifteen articles were reviewed. There are 6 coping strategies in leprosy patients that affect stress including reading books, social awareness programs, stigma, acceptance, social support and knowledge.

Result: From the results of the analysis, these can be applied to provide support for people affected by leprosy to change their coping mechanisms to allow them to be more adaptive.

Conclusion: These strategies need to be considered to determine the level of coping of an individual in dealing with stress stimulation in patients with leprosy originating from themselves, others and the environment.

\section{Keywords}

Strategy, stress, leprosy, coping 
Kutip sebagai:
Jatimi, A., Nenobais, A., Jufriyanto, M., Heru, M. J. A. \& Yusuf, A (2019). Mekanisme dan Strategi Mengurangi Stress pada Pasien Kusta. Indonesian J. of Community Health Nurs. J., 4(1), 41-45. Doi: 10.20473/ijchn.v4i1.17540

\section{PENDAHULUAN}

Kusta adalah penyakit menular yang menyebabkan permasalahan yang kompleks. Penyakit ini menyebar ke seluruh dunia dengan konsentrasi utama berada di negara-negara berkembang dengan kebersihan dan sanitasinya buruk. Menurut laporan resmi yang diterima dari 138 negara dari semua wilayah WHO, prevalensi kusta pada akhir 2015 adalah 176.176 kasus (0,2 kasus per 10.000 orang). Jumlah kasus baru yang dilaporkan secara global pada tahun 2015 adalah 211.973 (2,9 kasus baru per 100.000 orang). Pada 2014, 213.899 kasus baru dilaporkan dan pada 2013 terdapat 215.656 kasus baru. Jumlah kasus baru menunjukkan tingkat penularan infeksi yang berkelanjutan. Data statistik global menunjukkan bahwa 199.992 (94\%) kasus kusta baru dilaporkan dari 14 negara yang masing-masing melaporkan lebih dari 1000 kasus baru dan hanya 6\% dari kasus baru dilaporkan dari seluruh dunia. Kantong endemisitas tinggi masih tetap ada di beberapa wilayah di banyak negara, termasuk negara yang melaporkan kurang dari 1.000 kasus baru. Beberapa area ini menunjukkan tingkat pemberitahuan yang sangat tinggi untuk kasuskasus baru dan dengan demikian mereka masih menyaksikan transmisi yang intens.

Dampak penyakit kusta bagi penderita adalah meningkatkan stres secara emosional, sosial dan spiritual. Namun, yang paling dominan adalah penerimaan dan dukungan orang terdekat kepada mereka dan masyarakat terhadap orang yang terkena kusta. Dampak sosial penyakit ini sangat besar, menyebabkan keresahan yang sangat dalam, tidak hanya untuk klien itu sendiri tetapi juga untuk keluarga mereka, komunitas dan negara secara keseluruhan. Inilah yang mendasari konsep penerimaan klien terhadap perilaku terhadap penyakit, di mana untuk kondisi ini, klien masih menganggap bahwa kusta adalah penyakit menular, tidak dapat disembuhkan, dan turun-temurun yang dianggap sebagain kutukan Tuhan, hal ini merupakan suatu pelabelan dan prasangka terhadap kusta, selain

itu juga mempengaruhi psikologi pasien kusta dan menjadi pendorong untuk pemulihan. Di sisi lain diskriminasi yang terjadi di masyarakat dan yang dilakukan oleh orang yang paling dekat dengan penderita kusta karena takut tertular itu menjadi faktor pemicu stres. Orang yang mengalami stres menjadi gugup dan merasakan kecemasan yang berkepanjangan. Mereka sering menunjukkan sikap yang tidak kooperatif, lebih agresif, tidak rileks atau menunjukkan sikap ketidakmampuan mengatasinya (Malayu S.P.Hasibuan, 2013). Stres yang bekepanjangan dapat mengancam kemampuan seseorang untuk beradaptasi dengan lingkungan (De Kloet E R \& Molendijk, 2016). Namun, karena kurangnya pengetahuan dan pelatihan tentang metode koping, hal ini mampu menjadi pemicu harga diri rendah sehingga dibutuhkan startegi koping yang efektif untuk meningkatkan harga diri (Zaki, Kotb, \& Mohammed, 2020).

\section{METODE}

Basis data yang digunakan adalah Scopus, Google Scholar, Science Direct, PubMed, dan Proquest dengan kata kunci berikut: kusta, pasien kusta, mekanisme koping, strategi koping, stigma, stres. Selanjutnya, kami menentukan kriteria inklusi dan eksklusi dan alat penilaian kritis. Kriteria inklusi adalah studi kualitatif dan studi kuantitatif dan artikel berbahasa Inggris dengan tahun publikasi antara 2014 sampai 2018. Kriteria untuk pengecualian artikel kuantitatif adalah mereka yang tidak mempunyai mekanisme koping dan strategi pasien kusta. Mencari literatur sesuai dengan kata kunci dalam database Scopus menemukan 104 artikel, sementara ada 231 artikel di Google Cendekia, 1032 artikel di Science Direct, 192 artikel di PubMed dan 103 artikel di Proquest. Secara total, 926 artikel potensial memenuhi kriteria, meskipun 462 artikel adalah sama, sementara 464 artikel potensial cocok dengan kriteria. Setelah seleksi menurut abstrak, 423 tidak relevan dan tidak bisa dibuka. Akhirnya, 41 artikel lengkap dipilih, 26 dikeluarkan dan sisanya 15 artikel memenuhi kriteria inklusi.

Mengekstraksi dan mensintesis data dari studi yang telah dipilih menggunakan tabel ringkasan yang berisi data tentang penulis, tahun publikasi, negara, tujuan, metode pengumpulan data, metode analisis data, dan hasil penelitian. Hasil penelitian kemudian disintesis dengan mengelompokkan setiap topik yang ditemukan.

\section{HASIL}

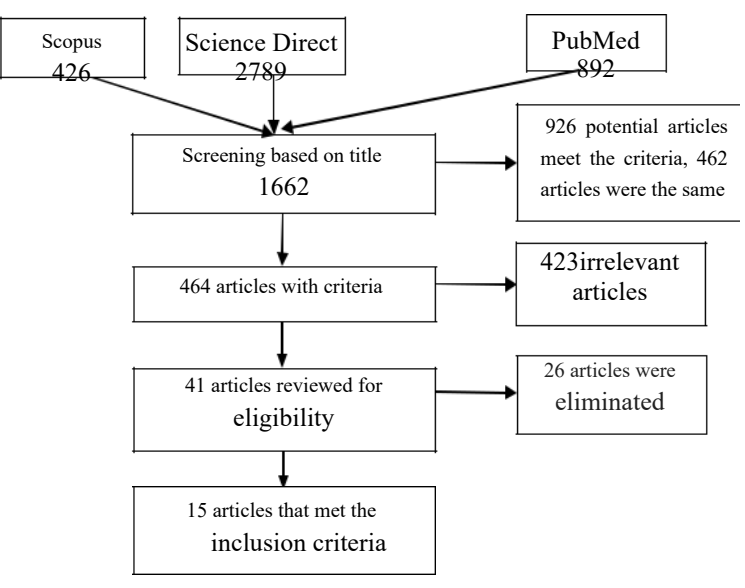


Berdasarkan penelitian yang ditinjau, ada 6 strategi koping pada pasien kusta yang mempengaruhi stres termasuk membaca buku, program kesadaran sosial, stigma, penerimaan, dukungan sosial dan pengetahuan.

\section{Membaca Buku}

Buku adalah sumber informasi yang dapat membuka cakrawala kita tentang berbagai hal seperti sains, ekonomi, sosial, budaya, politik dan aspek kehidupan lainnya. Membaca buku adalah cara untuk membuka jendela sehingga kita bisa tahu lebih banyak tentang dunia yang belum kita ketahui sebelumnya. Kegiatan ini dapat dilakukan siapa saja termasuk anak-anak, remaja, orang dewasa dan orang yang sudah lanjut usia - termasuk pasien yang menderita penyakit akut atau kronis di rumah atau di rumah sakit. Pasien yang menderita penyakit akut atau kronis biasanya akan mengalami kebosanan dan stres. Membaca selama beberapa menit dapat membantu menekan perkembangan hormon stres, seperti hormon kortisol. Membaca dapat membuat pikiran lebih rileks yang dapat membantu mengurangi tingkat stres. Selain relaksasi, membaca buku dapat membawa kedamaian batin. Ini sejalan dengan penelitian yang dilakukan oleh George et al. Pada tahun 2016, penelitian menunjukkan bahwa buku bacaan (biblioterapi) mampu mengurangi tingkat stres pada pasien, terutama dalam penelitian ini, yang menderita penyakit Hansen. Kegiatan membaca akan membantu klien untuk mengadopsi mekanisme koping yang lebih baik sehingga dapat menjalani kehidupan yang efektif terlepas dari penyakit dan kecacatan (George \& Ancheril, 2016).

\section{Program Kesadaran Sosial (social awareness)}

Program kesadaran sosial pada kusta adalah tindakan perbaikan potensial untuk mengurangi stigma sosial tentang kusta seperti pelabelan dan diskriminasi (Arachchi, M A J D M Kumari, A G D, Wickramasinghe, R Kuruppu \& Pramuditha, 2017). Tujuan dari program ini adalah untuk meningkatkan kesadaran di masyarakat dan penyedia layanan kesehatan (Muthuvel et al., 2017). Masyarakat umum harus sadar bahwa kusta bukanlah kelainan genetik dan 100\% dapat disembuhkan (Grzybowski, Sak, Pawlikowski, \& Nita, 2016). Meningkatkan kesadaran masyarakat tentang penyembuhan dari kusta dapat memotivasi pasien kusta untuk menunjukkan perilaku adaptif dengan mengadopsi mekanisme koping yang lebih baik.

\section{Stigma}

Penederita kusta yang telah mengalami cacat fisik akan mengalami stigmatisasi sosial, termasuk potensi untuk dikeluarkan dari masyarakat (Garbin, Garbin, Carloni, Rovida, \& Martins, 2015). Diskriminasi yang dilakukan merupana seutau bentuk penghapusan fungsi peran termasuk pembatasan kegiatan, diskriminasi dan pembatasan partisipasi sosial (Grzybowski et al., 2016). Hal ini memberikan dampak negatif pada emosi, pikiran, perilaku dan hubungan mereka (Bunders et al., 2015). Terjadinya stigma sosial tidak hanya untuk pasien yang terkena kusta tetapi juga untuk keluarga yang merawat mereka. Stigma keluarga berkaitan dengan kejadian stres keluarga sehingga ini mempengaruhi perawatan anggota keluarga yang menderita kusta(Suwandi \& Hadi, 2018). Dalam sebuah penelitian yang dilakukan oleh Kaehler pada tahun 2015, ditemukan bahwa perlakuan negatif dan diskriminasi terhadap penderita kusta masih sering ditemukan di antara mereka karena rasa malu di masyarakat. Ini ditemukan sebanyak $54,5 \%$ pada penderita kusta. Mereka yang tidak suka membeli makanan dari orang yang terkena kusta adalah $49,8 \%$ dan kesulitan mencari pekerjaan bagi orang yang terkena kusta dirasakan oleh 47,1\% (Kaehler, Adhikar, Raut, Marahatta, \& Chapman, 2015). Untuk alasan ini, masyarakat umum harus disadarkan bahwa kusta bukanlah kelainan genetik sehingga penderita kusta dapat terus hidup dalam damai dan menunjukkan perilaku adaptif yang lebih baik dan mekanisme penanganan positif.

\section{Penerimaan}

Secara umum pasien setelah didiagnosis kusta, akan mengalami krisis kepercayaan diri di mana mereka tidak dapat menerima kondisi mereka. Penerimaan tidak hanya datang dari diri mereka sendiri tetapi dari keluarga dan masyarakat mereka. Berdasarkan hasil penelitian yang dilakukan oleh Sodik et al pada tahun 2016, seluruh keluarga pasien kusta menerima informasi dengan baik. Hal ini dapat dilihat dari perilaku informan yang dengan sabar dan rajin merawat dan mengantar pasien untuk berobat. Berbeda dengan masyarakat, masyarakat cenderung tidak biasa dalam menerima harapan penderita kusta dan hanya sebagian kecil dari masyarakat yang menerima penderita kusta (Sodik, 2016). Penerimaan dan penolakan penderita kusta dapat memengaruhi perilaku koping pasien.

\section{Dukungan Sosial}

Ketika seseorang dalam keadaan terpuruk, yang dibutuhkan adalah dukungan dari keluarga, lingkungan dan masyarakat. Ini terutama terjadi pada pasien dengan kebutuhan khusus seperti penderita kusta, di mana dukungan dari orang-orang di sekitar mereka dapat menjadi pemicu untuk mengurangi stres. Penolakan dan diskriminasi yang dirasakan dari keluarga dan masyarakat mereka dapat menjadi faktor pendorong terjadinya perilaku maladaptif pada pasien kusta. Masyarakat umum harus disadarkan bahwa kusta bukanlah kelainan genetik, bahwa itu dapat disembuhkan dan bahwa pasien memerlukan dukungan sosial dari orangorang di sekitar mereka dan lingkungan mereka (Grzybowski et al., 2016).

\section{Pengetahuan}

Penelitian sebelumnya menunjukkan bahwa masih ada kekurangan pengetahuan tentang penyakit yang berkontribusi terhadap stigma tingkat tinggi meskipun bertahun-tahun upaya untuk meningkatkan kesadaran oleh program pengendalian 


\section{A. JATIMI ET AL.}

kusta di Nepal. Pendekatan pedagogis yang berbeda harus dikembangkan, dievaluasi dan diadaptasi untuk mencapai tujuan pendidikan yang diinginkan. Salah satunya adalah meningkatkan kapasitas petugas kesehatan di tingkat masyarakat. Staf yang terlatih dengan baik, khususnya dalam konseling, dapat menjadi bagian dari solusi untuk menyebarkan pesan-pesan kunci yang lebih efektif tentang kusta kepada pasien. Penggunaan konselor yang berdedikasi, khususnya mantan pasien yang terkena kusta, harus digeneralisasi di luar pusat pelayanan kesehatan khusus (Correia et al., 2019). Berdasarkan pertimbangan yang dibuat, perlunya upaya terorganisir dari semua fasilitas perawatan kesehatan masyarakat, dalam arti bertindak kreatif, partisipatif dan berdialog tentang masalah kusta, memprioritaskan praktik pendidikan sebagai strategi pembangunan yang melibatkan rekonstruksi pengetahuan di antara pengguna, keluarga, komunitas dan profesional kesehatan (Rodrigues, Albino, Parreira, Mendes F R, Cordeiro, \& de, Oliveira Adário K D Fernandes, Pimenta E Duarte, 2016). Selain meningkatkan pengetahuan tentang kusta di semua lapisan masyarakat, pengetahuan tentang metode koping pada pasien kusta juga dibutuhkan. Ini karena kurangnya pengetahuan dan pelatihan mengenai metode koping di antara pasien kusta menyebabkan harga diri rendah di antara mereka dan penggunaan strategi koping yang efektif akan meningkatkan harga diri mereka (Zaki et al., 2020). Selain itu, ada cara lain yang dapat digunakan untuk meningkatkan pengetahuan, yaitu intervensi kontak yang telah terbukti efektif dalam meningkatkan pengetahuan dan meningkatkan sikap publik terhadap kusta (Peters et al., 2015). Ini relatif mudah untuk ditiru di tempat lain dan tidak memerlukan teknologi mahal.

\section{PEMBAHASAN}

Hasil analisis artikel yang telah dipilih sesuai dengan kriteria inklusi menunjukkan bahwa strategi koping yang mempengaruhi stres pada pasien kusta terdiri dari banyak hal. Membaca buku dapat secara signifikan mengurangi gejala depresi, stres dan kecemasan, sebagaimana dibuktikan oleh penelitian yang bertujuan untuk mengeksplorasi apakah ada perbedaan setelah perawatan antara buku yang diarahkan sendiri yang tidak diarahkan dan yang memandu iCBT dalam mengobati MDD (Smith et al., 2017). Ini juga didukung oleh penelitian lain yang menunjukkan bahwa biblioterapi untuk pengobatan depresi dalam perawatan primer telah terbukti bekerja lebih baik dibandingkan dengan manajemen farmakologis (Scott, 2018).

Program kesadaran sosial diterapkan untuk meningkatkan wawasan dan pengetahuan masyarakat sehingga mereka dapat menunjukkan kepedulian mereka terhadap berbagai bidan, termasuk di sektor kesehatan. Sebuah studi program kesadaran berbasis sekolah dilakukan untuk mendukung pernyataan ini. Hasil penelitian menunjukkan bahwa ada beberapa tingkat peningkatan setelah program kesadaran dilakukan. Penelitian lebih lanjut tentang implementasi program kesadaran kesehatan mental berbasis sekolah universal diperlukan untuk menggunakan desain studi RCT, dan harus ada implementasi tindak lanjut jangka panjang (Salerno, 2017). Intervensi kesadaran menggunakan sukarelawan komunitas dan media, dengan informasi tentang penyebab kusta, manifestasi klinis dan pesan-pesan kesesuaian dan kepekaannya memperbaiki kesalahpahaman dan kepercayaan mengenai kusta, dapat meningkatkan pengetahuan masyarakat dan sikap terhadap kusta. Ini pada akhirnya akan berkontribusi pada pengurangan beban kusta di masyarakat (N, 2018). Menyusun strategi program kesadaran sesuai dengan karakteristik sosial-demografi berguna untuk meningkatkan pengetahuan tentang penyebab, gejala, penularan, pencegahan, dan pengobatan kusta. Ini dapat menumbuhkan sikap masyarakat yang positif terhadap orang-orang yang terkena kusta. Meningkatkan sikap positif terhadap orang yang terkena kusta dapat mengurangi stigma masyarakat, sehingga hal ini dapat meningkatkan partisipasi mereka dalam masyarakat. Sikap positif selanjutnya dapat meningkatkan perilaku pencarian kesehatan awal mereka, termasuk kualitas hidup mereka (Singh, Singh, \& Mahato, 2019).

Stigma adalah asumsi atau penilaian seseorang terhadap orang lain dan lingkungannya. Stigma negatif dapat memiliki dampak negatif pada korban, tetapi dapat diatasi atau dicegah dengan anti -stigma karena penelitian pendukung menunjukkan bahwa intervensi anti-stigma di tempat kerja dapat meningkatkan pengetahuan karyawan dan perilaku mendukung terhadap orang-orang dengan kesehatan mental. masalah. Efek intervensi pada sikap karyawan beragam tetapi umumnya positif (Hanisch et al., 2016). Kualitas bukti bervariasi di seluruh studi.

Penerimaan adalah rasa ketulusan terhadap sesuatu yang positif atau negatif termasuk diri, orang lain, dan lingkungan. Ini termasuk menerima kondisi kesehatan ketika dalam keadaan sakit dan menerima penilaian orang lain yang negatif dan menyakitkan. Penelitian yang mendukung penerimaan diri menyatakan bahwa tahap penerimaan diri dilewatkan oleh subjek, yaitu persembahan, kemarahan, dan penerimaan. Faktorfaktor yang juga mempengaruhi penerimaan diri subjek adalah wawasan sosial ke dalam pengakuan diri, religiusitas dan dukungan dari orang terdekat (Wijanarko \& Ediati. A, 2016). Penerimaan diri subjek dapat dilihat dari sikap positif subjek terhadap masalah yang mereka hadapi, seperti bersyukur atas cobaan yang dirasakan. Yang terakhir adalah dukungan sosial. Dukungan sosial adalah dukungan moral positif dari orang lain dan lingkungan. Hal ini bertujuan untuk meningkatkan keamanan dan kenyamanan mereka sehingga dapat meningkatkan motivasi untuk menjadi lebih baik. Tingkat stres dan dukungan sosial 
saat ini terkait dengan gejala depresi dan kecemasan (Riaz, Wolden, Gelblum, \& Eric, 2016),

Keterbatasan penelitian ini adalah sebaran responden data tidak mewakili semua negara yang berpartisipasi, sehingga ini dapat membawa risiko bias yang lebih tinggi. Ini karena budaya, kehidupan sosial, pola pikir dan tingkat pengetahuan di masingmasing daerah berbeda

\section{KESIMPULAN}

Hasil analisis artikel menemukan ada 6 strategi koping pada pasien kusta yang mempengaruhi stres, termasuk membaca buku, program kesadaran sosial, stigma, penerimaan, dukungan sosial dan pengetahuan. Strategi-strategi ini perlu dipertimbangkan untuk menentukan tingkat koping individu dalam menghadapi stimulasi stres pada pasien dengan kusta yang berasal dari diri mereka sendiri, orang lain dan lingkungan.

\section{DAFTAR PUSTAKA}

Arachchi, M A J D M Kumari, A G D, Wickramasinghe, R Kuruppu, N. R., \& Pramuditha, M. A. V. (2017). Stigmatization in Leprosy: A descriptive study from patients' perspective in Sri Lanka. Sci. Res. J., 5

Bunders, J. F. G., Zweekhorst, M B M, Cummings, S., Irwanto, Seda, F. S. S. E., Miranda-Galarza, B., Peters, R. M. H., \& Lusli, M. (2015) . Dealing with Stigma: Experiences of Persons Affected by Disabilities and Leprosy. Biomed Res. Int., 1-9.

Correia, J. C., Golay, A., Lachat, S., Singh, S. B., Manandhar, V., Jha, N., ... Beran, D. (2019). "If you will counsel properly with love, they will listen": A qualitative analysis of leprosy affected patients' educational needs and caregiver perceptions in Nepal PLoS One. 14, 1-15.

De Kloet E R, D., \& Molendijk, M. L. (2016). Coping with the Forced Swim Stressor: Towards Understanding an Adaptive Mechanism Neural Plas.

Garbin, C. A. S., Garbin, A. J. Í., Carloni, M. E. O. G., Rovida, T. A. S., \& Martins, R. J. (2015). The stigma and prejudice of leprosy: Influence on the human condition. Rev. Soc. Bras. Med. Trop., 48, 194-201.

George, R., \& Ancheril, A. (2016). Effectiveness of Bibliotherapy on Stress among Patients with Hansen's Disease Ancheril Nursing. Internatioanl J. Sci, (5), 5-6.

Grzybowski, A., Sak, J., Pawlikowski, J., \& Nita, M. (2016). Leprosy: Social implications from antiquity to the present. Clin. Dermatol, 34, 8-10.

Hanisch, S. E., Twomey, C. D., Szeto, A. C. H., Birner, U. W., Nowak, D., \& Sabariego, C. (2016). The effectiveness of interventions targeting the stigma of mental illness at the workplace: A systematic review. BMC Psychiatry, 16, 1-11.

Kaehler, N., Adhikar, B., Raut, S., Marahatta, S. B., \& Chapman, R. S. (2015). Perceived stigma towards leprosy among community members living close to Nonsomboon leprosy colony in Thailand PLoS One. 10, 1-10.
Malayu S.P.Hasibuan. (2013). Manajemen Sumber Daya Manusia. Jakarta: Bumi Aksara.

Muthuvel, T., Govindarajulu, S., Isaakidis, P., Shewade, H. D., V, R., Singh, R., \& Kamble, S. z. (2017). "I Wasted 3 Years, Thinking It's Not a Problem": Patient and Health System Delays in Diagnosis of Leprosy in India: A Mixed-Methods Study PLoS Negl. Trop. Dis, (11), 1-15.

N, A. K. (2018). Community knowledge, perceptions and attitudes regarding leprosy in rural Cameroon: The case of Ekondotiti and Mbonge health districts in the South-west Region. PLoS Negl. Trop. Dis., 12, 1-7.

Peters, R. M. H., Dadun, Zweekhorst, M. B. M., Bunders, J. F. G., Irwanto, \& van, B. W. H. (2015). A Cluster-Randomized Controlled Intervention Study to Assess the Effect of a Contact Intervention in Reducing Leprosy-Related Stigma in Indonesia PLoS. Negl. Trop. Dis., 9.

Riaz, N., Wolden, S. L., Gelblum, D. Y., \& Eric, J. (2016). Zipping and unzipping: protein modifications regulating synaptonemal complex dynamics. 118, 6072-8.

Rodrigues, N. V. A., Albino, S. C., Parreira, Mendes F R, Cordeiro, de O. R. de C., \& de, Oliveira Adário K D Fernandes, Pimenta E Duarte, de S. L. (2016). Manifestations of Stigma and Prejudice Informed by Treated Lepers. Int. Arch. Med.

Salerno, J. P. (2017). Effectiveness of universal school-based mental health awareness programs among youth in the US: a systematic review. J. Sch. Health, 86, 922-931.

Scott, S. (2018). Primary Care Provider Attitudes towards Adoption of Evidence Based Practice: Indicators of Acceptance towards Bibliotherapy.

Singh, R., Singh, B., \& Mahato, S. (2019). Community knowledge, attitude, and perceived stigma of leprosy amongst community members living in Dhanusha and Parsa districts of Southern Central Nepal. PLoS Negl. Trop. Dis., 13, 1-19.

Smith, J., Newby, J. M., Burston, N., Murphy, M. J., Michael, S., Mackenzie, A., ... Andrews, G. (2017). Help from home for depression: A randomised controlled trial comparing internet-delivered cognitive behaviour therapy with bibliotherapy for depression. Internet Interv., 9, 25-37.

Sodik, M. A. (2016). ISSN (Vol. 1).

Suwandi, T., \& Hadi, C. (2018). Analysis of the effect of Individual, Familial and Environmental Factors on Family Stigma of Leprosy in Jombang regency, East Java Indonesia. The 2nd Joint International Conferences, 29, 264-270.

Wijanarko, A., \& Ediati. A. (2016). Penerimaan Diri Pada Orangtua Yang Memiliki Anak Skizofrenia. J. Psikol., 5, 424-9.

Zaki, S. M., Kotb, F. N., \& Mohammed, A. A. (2020). Assessment of Self-Esteem and Coping Strategies among Leprotic Patients. 7, 109-115. 